\title{
Miten aikuiskasvatuksen tutkimus palvelee käytäntöä?
}

Ihmistieteiden itsetutkistelussa on viime aikoina kyselty, edistyykö tiede ja edistymisen kriteerien asettaminen on osoittautunut peräti ongelmalliseksi monien tieteenkäsitysten ja paradigmakriisien keskellä. Aikuiskasvatustieteessä tällaiset tieteenteoreettiset kysymykset ovat kaksin verroin hankalia, kun koko tieteenalan teoreettiset perusteet ovat vasta alkutekijöissään. Syventymättä niihin otan seuraavassa esille joitakin näkökohtia aikuiskasvatuksen tieteellisen tutkimuksen suhteesta käytännön aikuiskasvatustoiminnan harjoittamiseen. Käytäntöön sisällytän myös hallinnon eri tasot valtion aikuiskoulutuspolitiikkaa myöten.

Kun on puhe aikuiskasvatustutkimuksen tieteellisestä edistymisestä, yksi lähtökohta on välttämättömyys rakentaa tämän tutkimuksen teoreettisia perusteita alkaen kysymyksistä, mitä aikuiskasvatus on perusluonteeltaan, mitkä ovat sen tehtävät, mahdollisuudet ja edellytykset. Tämä vaatii sekä kasvatusfilosofista tutkimusta että sellaista teorianmuodostusta edistävää empüiristä tiedonhankintaa, jota on tapana nimittää perustutkimukseksi - näitä kahta kiinteässä keskinäisessä yhteydessä. Empiirisen tutkimuksen edetessä hajanaisesti ja erillisinä saarekkeina teoreettisten perusteiden systemaattinen kehittäminen on jäänyt pahasti jälkeen.

Toinen lähtökohta on siinä peruskäsityksessä, että aikuiskasvatustiede on muiden kasvatustieteiden tavoin käytännöllinen tiede, jonka tehtävänä on viime kädessä palvella aikuiskasvatuskäytännön kehittämistä ja sen päämäärien toteuttamista. Onnistuminen tässä tehtävässä tulee siten tieteen edistymisen kriteeriksi. Ne tutkimuksen kehittämisen vaatimukset, joihin esitetyt kaksi vaatimusta johtavat, saattavat käytännön edustajasta näyttää keskenään ristiriitaisilta. Tuttu tosiasiahan on, että käytännön edustajien tapa arvioida tutkimuksen arvoa on usein varsin suoraviivainen: odotetaan selviä menettelyohjeita tai ainakin täsmällisiä ratkaisuperusteita konkreettisiin käytännön pulmiin. Käytännöllistä on tutkimus, joka asettaa ongelmansa käytännön tilanteista ja etsii niihin ratkaisumahdollisuuksia.

Käytännön kehittämistoimintaan kiinteästi liittyvää tutkimusta tietysti tarvitaan. Liiankin monia kalliita kokeiluhankkeita on pantu toimeen ja koulutusinnovaatioita toteutettu ilman että tutkimuksen apua olisi käytetty enempää suunnittelu- kuin arviointivaiheessakaan. Toisaalta meilläkin on, nimenomaan koulujärjestelmän puolella, pitkät sarjat esimerkkejä tavoitetutkimuksesta, joka teoreettisen perustan pettäessä ei ole hyödyttänyt käytännön kehittämistoimintaakaan. Tärkeintä kuitenkin on, että teoreettisen syventymisen ja sitä mukaa tieteellisen edistymisen mahdollisuudet jäävät sitä heikommiksi, mitä hallitsevammin aktuaaliset käytännön tarpeet pääsevät ohjaamaan tutkimuksen suuntautumista. Samalla vaarantuvat tieteellinen vapaus ja tutkijain edellytykset toteuttaa yhteiskuntakriittistä tehtäväänsä. Aivan viime kuukausina on tiedeyhteisön omassakin piirissä - Professoriliitto varoittavana esimerkkinä - vaadittu voimistunein äänenpainoin, että tutkimuksen on kiinteämmin palveltava hallintokoneis- 
ton ja elinkeinoelämän kysyntää. Tällaiset tendenssit vaativat aktiivista valppautta aikuiskasvatuksenkin alueella.

Ahtaat käytännöllisyyden tulkinnat ovat osaltaan johtaneet siihen, että aikuiskasvatustieteelliseksi käsitetään kaikki se tutkimus, joka tavalla tai toisella käyttää aineistonaan aikuiskasvatustoimintaa tai - esimerkiksi psykologian alueella - kohdistuu aikuisten elämänkulkuun, kehittymiseen tai oppimiseen. Tällainen ajattelutapa johtaa siihen, että aikuiskasvatuksen omien teoreettisten perusteiden kehittäminen - mikäli sellaista edes pidetään tarpeellisena - tapahtuu poimimalla psykologian, sosiologian ja muiden tieteiden ajatteluvälinein tutkitusta tiedosta sellainen aines, joka on käytännön aikuiskasvatustyön kannalta relevanttia ja käyttökelpoista. Tämä olisi kovin hatara ja sattumanvarainen tapa syventää aikuiskasvatuksen itseymmärryksen tieteellistä perustaa.

Sama ajattelutapa, joka toisaalta häivyttää eron aikuiskasvatusilmiöitä koskevan tutkimuksen ja aikuiskasvatustieteellisen tutkimuksen väliltä, on toisaalta omiaan johtamaan tutkimusalan typistämiseen: aikuiskasvatustieteen alan määrittely samastetaan organisoidun aikuiskasvatustoiminnan alaan, mistä johdonmukaisesti seuraisi että vain tämä toimintakenttä kuuluu tutkimuksen kohdealueeseen. Tutkimuksen ala muodostuu olennaisesti laajemmaksi, jos lähdetään siitä että aikuiskasvatustieteen tehtävänä on syventää ja tarkentaa tietoisuutta aikuiskasvatuksen perusluonteesta: mitkä ovat kasvatuksellisen vaikuttamisen päämäärät, keinot ja mahdollisuudet silloin kun kyseessä on aikuisten oppimisen ja jatkuvan kehittymisen tukeminen ja tarkoituksellinen ohjaaminen. Tietoa aikuisten kehittymisen ehdoista ja mahdollisuuksista voidaan ja tulee hakea kaikista niistä elämänmuodoista, joissa aikuinen jatkuvasti oppien toimii. Tutkimuksen tekee aikuiskasvatustieteelliseksi sen oma erityinen peruskysymys: miten tietoisella kasvatuksellisella vaikuttamisella voidaan edistää päämäärähakuisesti ihmisten ja heidän kulttuurinsa kehittymistä. Yksittäisissä empiirisissä tutkimuksissa on viitetaustaa, ongelmanasettelua ja tavoitteita rajoitettava. Väitän kuitenkin, ettei aikuiskasvatuksen ilmiöihin kohdistuva tutkimus ole varsinaisesti aikuiskasvatustieteellistä, jos siitä kokonaan puuttuu kasvatuksellinen kysymyksenasettelu.

F.E. Sillanpää määritteli aikoinaan hyvän kirjan tunnuspiirteeksi, että se vapauttaa ajattelua siitä, mikä tässä elämässä pyrkii liiaksi järjestymään. Aikuiskasvatustutkimuksenkin keskeinen tehtävä on asettaa kyseenalaiseksi ne käsitykset, uskomukset ja toimintamallit, jotka käytännön aikuiskasvatustyössä ovat vakiintuneet itsestäänselvyyksiksi. Tähän on oltava moraalista rohkeutta, vaikka totuudenpuhuja kohtaisikin vaikeuksia yösijan saamisessa. Toinen vaihtoehto on leipääntyminen käytännön palvelijaksi, joka noudattaa entisen rengin periaatetta 'Niin tehdään kuin isäntä sanoo eikä niinkuin hyvä olisi’’.

Pohtiessaan sosiaalipsykologian tehtävää tietoisuuden havahduttajana Antti Eskola esittää kysymyksen, onko tutkija valmis toimimaan yhdessä muiden kanssa silloin, kun loukusta selviäminen vaatii siirtymistä maailman selittämisestä sen muuttamiseen. Sama kysymys on tehtävä sekä käytännön aikuiskasvattajalle että aikuiskasvatuksen tutkijalle. 